\title{
WestVirginiaUniversity
}

THE RESEARCH REPOSITORY @ WVU

Graduate Theses, Dissertations, and Problem Reports

2016

\section{Framing 2014 Hong Kong Protest}

Liying Ye

Follow this and additional works at: https://researchrepository.wvu.edu/etd

\section{Recommended Citation}

Ye, Liying, "Framing 2014 Hong Kong Protest" (2016). Graduate Theses, Dissertations, and Problem Reports. 7004.

https://researchrepository.wvu.edu/etd/7004

This Thesis is protected by copyright and/or related rights. It has been brought to you by the The Research Repository @ WVU with permission from the rights-holder(s). You are free to use this Thesis in any way that is permitted by the copyright and related rights legislation that applies to your use. For other uses you must obtain permission from the rights-holder(s) directly, unless additional rights are indicated by a Creative Commons license in the record and/ or on the work itself. This Thesis has been accepted for inclusion in WVU Graduate Theses, Dissertations, and Problem Reports collection by an authorized administrator of The Research Repository @ WVU. For more information, please contact researchrepository@mail.wvu.edu. 


\title{
Framing 2014 Hong Kong Protest \\ Liying Ye
}

\author{
Dissertation submitted \\ to the Reed College of Media \\ at West Virginia University \\ in partial fulfillment of the requirements for the degree of \\ Master of Science in \\ Journalism
}

Steve Urbanski, Ph. D., Chair
Bob Britten, Ph.D.
David Smith, M.A.
Ji Young Lee, Ph.D.
Department of Reed College of Media

Morgantown, West Virginia

2016

Keywords : news frames, media system, Hong Kong protest, content analysis

Copyright 2013 Liying Ye 


\section{ABSTRACT \\ Framing 2014 Hong Kong Protest}

\section{Liying Ye}

Numerous newspapers have documented the stories of the 2014 Hong Kong protest, but there was a void of systematic analysis of the protest coverage. To partially fill this gap, this study utilized the most five common news frames- conflict, human interest, responsibility attribution, morality, economic consequence- to probe how they were used in different newspapers within their media systems. The attitudes, or tone, towards the Hong Kong protest was also examined to gain an in-depth understanding in relation to different framing strategies. A total of 105 news article from China Daily (Mainland China), South China Morning Post (Hong Kong) and New York Times (the United States) were selected for content analysis. Through empirical data collected, it was found that conflict, human interest, and responsibility attribution were the most frequent used framing strategies in reporting 2014 Hong Kong protest. The frame of economic consequence was associated with the negative tone of the protest. Neutral tone was the dominant attitude towards the Hong Kong protest. 


\section{Table of Contents}

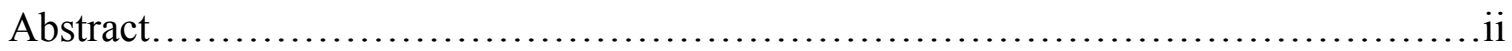

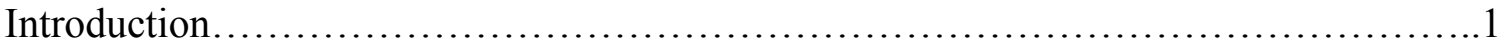

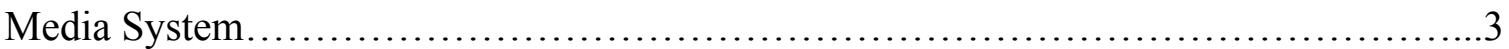

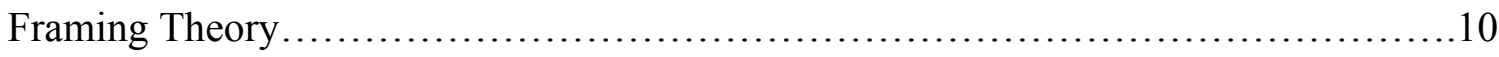

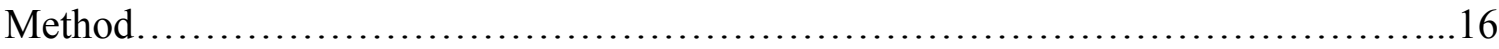

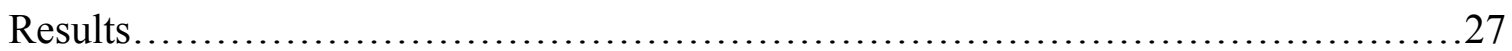

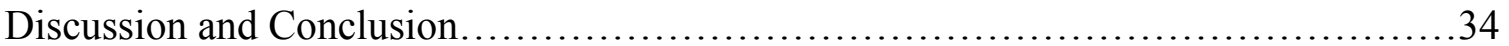

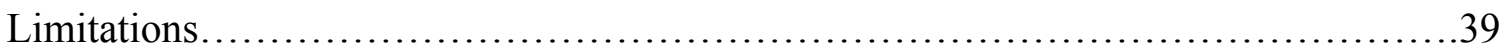

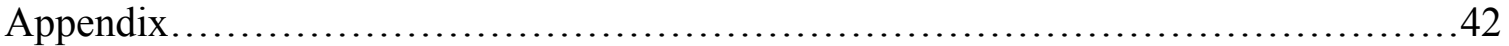

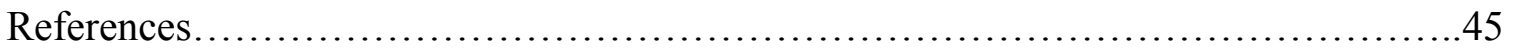

List of Tables

Table 1. Total Number of Stories by Newspaper and Overall Tone of Story .............28

Table 2. Frequency of Dominant Frame by Newspaper.............................28

Table 3. Frequency of News Frames by Newspaper Title...............................30

Table 4. Number of News Frames by Overall Tone of Story ..........................31

Table 5. Mean Scores of the Frequency of Use of News Frames and Overall Tones by

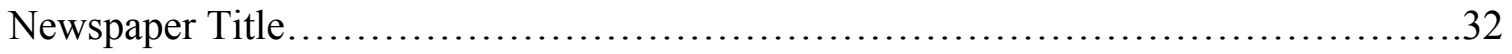




\section{Introduction}

On August 31, 2014, the National People's Congress Standing Committee (NPCSC) of the People's Republic of China made a decision on proposed reforms to Hong Kong electoral system for the 2017 Hong Kong Chief Executive election and the 2016 Legislative Council election. According to NPCSC, two or three candidates should be elected from 1,200-member Nominating Committee based on the present Election Committee before listing them on the territory-wide ballot by Hong Kong people.

The announcement frustrated people in Hong Kong, since the NPCSC appeared to break the earlier promise in 2007 of implementing universal suffrage to elect the fifth Chief Executive of the Hong Kong Special Administrative Region in 2017. The decision was perceived as the Communist Party's control over the potential candidates to represent themselves to the Hong Kong electorate (Cheung, 2014).

Major political factions in Hong Kong launched their campaigns to advocate their ideas on how to achieve universal suffrage in the 2017 Chief Executive election, such as the Occupy Central with Love and Peace, an active advocacy group that pressured the Beijing government. The atmosphere became intense in late September as protests were held by political activist groups such as Scholarism, the Hong Kong Federation of Students (HKFS) and Occupy Central with Love and Peace (OCLP), demanding the rescission of the NPCSC decision. Triggered by the police's use of tear gas, pepper spray and attacks, "tens of thousands" of protesters participated in the occupation of key areas in Admiralty, Causeway Bay and Mong Kok (BBC News, 2014). On September 29, 89 
protesters were under arrest, and 41 others injured (Curran, The Wall Street Journal, 2014). Government operations and schools were closed due to the safety concerns.

The movement raised concerns from other nations worldwide. The UK Prime Minister David Cameron expressed deeply concerns about the clashes in Hong Kong and felt obligated to speak out the events (Faulconbridge, 2014); the Canadian Foreign Affairs Minister John Baird supported for the implementation of universal suffrage for the Hong Kong election (Chase, 2014); the United States Consulate General stated its strong support for Hong Kong's protections and recognition of fundamental freedoms and clarified "we do not take sides in the discussion of Hong Kong's political development, nor do we support any particular individuals or groups involved in it" (Chu, 2014); the United Nations Human Rights Committee urged China to allow free elections in Hong Kong (Forsythe, 2014).

Chinese national media China Daily reported (Bastin, 2014) that the movement damaged the image of Hong Kong as a financial and fashion hub of the world. It also accused the U.S. media of deliberately misleading and stirring up Hong Kong society. United States and other foreign nations were warned by the Chinese Foreign Ministry to stay out of Hong Kong's affairs and reminded that the issue was China's internal affairs. Government officials in Beijing and in Hong Kong condemned the occupy movement as illegal and it violated the rule of law.

Information about the movement on social media such as Facebook, Twitter, Instagram, Sina Weibo, Tecent Weibo and Wechat were blocked in Mainland China. Local newspapers avoided covering the negative impacts of the movement, and the Chinese version of Reuters and the Wall Street Journal did not mention the Hong Kong 
protest. American and European media paid close attention to the unrest development and covered the stories on the spots.

On December 15, the police cleared the protesters and their camps in peaceful way, which brought the protests to an end with no political compromises from the government.

\section{Media System}

Journalistic practice from different regions is affected by its media system. And the differences in media systems are a result of differences in "laws and regulations," "links between media and political parties," "journalistic professional traditions" and "the structure of audience and advertising markets" (Benson et al., 2012, p. 22). Therefore, before probing how different newspapers frame the same issue in diverse ways, it is essential to gain clear background knowledge of each newspaper's media system. Since this study selected three newspapers from disparate regions, the media system in China, Hong Kong and the United Stated will be analyzed below.

\section{China}

Mass media in China have been strategically controlled by the propaganda system of the Chinese Communist Party (CPP) for decades (Han, 2007, p. 43). Media has been long considered as the "throat and tongue" of the party, fulfilling its duty and mission to spread CPP'S political ideology, guide and educate the public's judgments and gain public support. Two crucial departments - the Central Propaganda Department (CPD) and the State Council Information Office (SCIO) - have been orchestrating the censorship. The former monitors the contents of print media, television, and radio, sending 
to its provincial and municipal branches about the "instructions to publications several times a week by fax or telephone about what topics not to report on and what topics to play down or up," while the latter regulates the content of online news sites by "contacting the editors of large websites to orchestrate their coverage of important events" (Tai, 2014, p. 189).

Extremely sensitive topics, including Tibetan and Uighur separationist movements, political reform and democracy, labor protests and human rights activities, are more likely to be strictly censored. Reports of religion, protests and individual dissidents have the biggest chance of being banned (Tai, 2014, p. 189-201). With regards to the surveillance in cyber space, the government's censorship screens out unfavorable content such as pornography, gambling, or anti-government materials from foreign language and Chinese websites. (Han, 2007, p. 45).

To look at the changes to Chinese censorship practice in recent years, Tai (2014) conducted a content analysis to examine 1,403 secret censorship directives issued by Chinese propaganda apparatus from an independent, uncensored, bilingual news website China Digital Times. After identifying the censorship authorizations, examining issue areas that tended to be regulated and banned, and tracking how censorship decision changed, Tai found that the Chinese Communist Party (CCP) enforced censorship to restrain undesired reports by providing "conditional public opinion guidance."

Han (2007) considered the CPP's control of censorship of "non-political" media content had been much looser since the reform and open policy in 1978, but what Stockman (2013) found was that media marketization under the reform and open policy 
actually strengthens the Chinese government's competency in disseminating information via promoting credibility of the media's coverage.

Tai (2014) was likely to support Stockman. The government was faced with critical challenges under the rapid development of Internet and social media, and it became more difficult to watch every piece of information shared on and off line. However, the government has been flexible enough to adjust the "ban " strategy to "ban, restrict, encourage" strategy (p. 187).

In addition, the government utilizes the world's most-advanced system for censoring and monitoring online news content, launched automated programs, and pay thousands of human censors to screen content generated by the users and delete posts that discorded the directives (King et al., 2013). According the Freedom House (2015), an annual survey of media independence among 199 countries and territories, China ranked 86 ("Not Free”), while Hong Kong stood 41(“Partly Free”) and United States placed 22 ("Free").

\section{Hong Kong}

As a first Special Administrative Region, Hong Kong confidently claimed itself as "a major media center" in East Asia. Because of the comparative loose regulation, ease of publication and reporters license, as well as people's awareness and initiative of expression, Hong Kong presents its superior media status by showing "the vibrancy of its locally focused media and the large number of regional media operations located in its midst" (Cullen, 1998, p. 391). Under the "one country, two systems" policy, Hong Kong enjoys quite a high level of autonomy. Though not completely democratic like the United 
States, its freedom in terms of social, economic and political development is somewhat equivalent to or better when compared to its neighbors. Because of a lower government interference on media and the private-owned media, Hong Kong is also a free port of information flow, although the government set limits on pornographic publications as well as sensitive political materials (Wilkins, 2008, p. 18).

The Basic Law of the Hong Kong Special Administrative Region of the People's Republic of China (Basic Law), which was in effect in 1997 when Hong Kong returned to Chinese rule, has been a dominant instrument to lead the city's development. Under the Basic Law, several statutory instruments are implemented to focus on Hong Kong's media development. Print publications need a license from the Registration of Local Newspapers Ordinance, while electronic media need to get approval from Television Ordinance, Broadcasting Authority Ordinance, and Telecommunication Ordinance. These ordinances, at some point, show support for the government. According to Cullen (1998), the Television Ordinance upholds the power that allows the Hong Kong government to set standards, demand to see materials prior to broadcasting, prohibit the broadcasting of some materials through seeking a court order. As the Telecommunication Ordinance, it permits the government to "order that certain messages be banned from transmission or that those messages be intercepted if it is in the public interest," and the Film Censorship Ordinance performs its duty to "censor films for cinema or television distribution on ground of moral offensiveness or social divisiveness" (p. 396).

In fact, before the Chinese central government took over Hong Kong and established it as a Special Administrative Region, there were many concerns on the practice of freedom of the expression under its rule. Thus, scholars in the communication 
field have paid particular attention to the Hong Kong media development over the years. Cullen (1998) looked at the changes of media regulation after the return of Hong Kong, as the political circumstances have changed over years. It has been suggested that the factors that may affect the level of content control are complex, such as "the effect of a given broadcast on law and order in Hong Kong," "likelihood of a given broadcast to incite hatred against any group based on race, color, sex, religion, nationality or ethnicity," and "likelihood of a given broadcast to gravely damage public health or morals" (Cullen, 1998, p. 396). Chan (2007) conducted case studies to support the claim that the threat to the freedom of the expression came from the abuse of press freedom by media itself, rather than government's interference.

Dissident opinion from Zhou (2009), who concluded the restraint of the right still existed under some guidelines and rules, though Chinese central government claimed its support for the right of freedom of expression following the Article 27 of the Hong Kong constitution. Zhou (2009) examined the content of a TV program, Current Affair Debate of Phoenix TV in Hong Kong, and found that it kept a nuanced balance between criticisms and support towards the government to achieve some level of freedom of speech. Hong Kong journalists showed disappointment at media development. According to a survey commissioned by Hong Kong Journalists Association (HKJA) in 2002, over $50 \%$ of journalists considered press freedom in Hong Kong as deteriorating since the 1997 Hong Kong return.

Similar to media in Mainland China, sensitive political topics such as subversive and separatist coverage of Taiwan, Xinjiang and Tibet, as well as the criticism of the Chinese leadership must also be banned in Hong Kong media (HKJA \& Article19, 1997). 
To survive, some Hong Kong newspapers switched their political stances. The Hong Kong Standard showed pro-HKSAR government slant in its coverage and the Sing Tao Daily gave up its stance towards the Taiwan issue (Cullen, 1998, p. 394). To assure freedom of press, the HKJA (2011) recommended that the next chief executive should resist pressure to enact national security legislation, review government policies on the release to the media, and take a robust line with Beijing over the treatment of Hong Kong journalists carrying out legitimate duties in Mainland China, etc.

\section{The United States}

As a democratic society, freedom of the press/speech is crucial feature protected by the First Amendment of the Constitution. The ratified Articles that constitutes the first 10 amendments of the Constitution, known as the Bill of Rights, articulate this protected right: "Congress shall make no law respecting an establishment of religion or prohibiting the free exercise there of; or abridging the freedom of speech, or of the press; or the right of the people peaceably to assemble, and to petition the Government for a redress of grievances" (Article the third, 1971).

To ensure comprehensive adherence to the First Amendment, a number of state and federal statues have been established- among them, the Freedom of Information Act and the Privacy Act. Besides, created by the Communications of Act of 1934, the duty of the Federal Communication Commission (FCC), as an independent agency of the United States government, is to "regulate interstate and international communications by radio, television, wire, satellite and cable in all 50 states, the District of Columbia and U.S. territories", with an emphasis on "revising media regulations so that new technologies 
flourish alongside diversity and localism" (FCC, 1934). To comprehensively execute its missions, the FCC established different bureaus for specified regulation. For example, the Media Bureau regulates electronic media, which includes cable television, broadcast television, and radio in the United States and its territories; the Wireline Competition Bureau, which works to ensure that all Americans have access to robust, affordable broadband and voice service; the Wireless Telecommunications Bureau administers all domestic commercial and private wireless telecommunications programs and policies; and the International Bureau, which manages all international programs.

Under the thorough protection of statues, the media in the United States enjoy a fairly high level of freedom, since there is no explicit or inexplicit government control over the media, such as subsidy, as well as official censorship pressures on the media. The media in the United States is considered as the Fourth Estate, because of its "watchdog" role over the government. In the United States, wealthy individuals often own almost all of the broadcast and print media. Under the free market environment, media are faced with fierce competition to gain profits by meeting with the public's needs and wants, which is characterized as "market driven" media (McManus, 1994). Giant newspaper companies such as Gannett, MediaNews Group, and News Corporation maintain big proportions of market share (Who Owns the News Media, 2012). As a result of the freedom of press, the media of the United States presents unique features of a liberal media system: Objective or impartial news reporting, professional journalism with the systems for self-regulation (Hallin \& Mancini, 2004). 


\section{Framing Theory}

The sociologist Erving Goffman (1974) was the first scholar to introduce the concept of framing and conducted the earliest frame analysis, which became a significant "theoretical approach in communication" (Chu, 2010, p. 7). He interpreted the primary framework as "one that is seen as rendering what would otherwise be a meaningless aspect of the scene into something that is meaningful", which provided access for its users to "locate, perceive, identify, and label a seemingly infinite number of concrete occurrences" (p. 21).

Originally, Goffman (1974) categorized the primary frameworks into natural framework and social framework. The function of social framework was to "provide background understanding for events that incorporate the will, aim, and controlling effort of an intelligence, a live agency, the chief one being the human being" and he depicted it as "guided doings" (p. 22).

In general, the journalistic framing, or media framing, and audience framing are the two processes of framing. Tuchman (1978) conceptualized the news frames "organizes everyday reality and the news frames is part and parcel of everyday reality" (p. 193), which were considered as "conceptual tools which media and individuals rely on to convey, interpret and evaluate information" (Neuman et al., 1992, p. 60). Similarly, Gitlin (1980) defined news frame as "persistent patterns of cognition, interpretation, and presentation of selection emphasis, and exclusion, by which symbol handlers routinely organize discourse, whether verbal or visual" (p. 7). With regards to audience frames, or individual frames, Entman (1993) defined it as "mentally stored clusters of ideas that guide individuals' processing of information" (p. 53). 
In terms of political and economic news, generic frames and issue-specific frames were suggested (de Vreese et al., 2001). Generic frames were summarized into five categorizes: responsibility frame, human interest frame, conflict frame, economy consequences frame, and morality frames (Semetko \& Valkenburg, 2000, p. 96). According to the Semtko and Valkenburg (2000), "conflict frame" stresses conflict between individuals, groups, or institutions as a highlight to attract audience's attention; "human interest frame" tries to invoke audience's emotion to personalize the news of an event, issue, or problem; "responsibility attribution frame" is attributing responsibility for the "cause or solution to either the government or to an individual or group" (p. 96) through the presentation of an event, an issue or a problem; "morality frame" is putting an event, an issue or a problem to induce moral question or discussion, by referring to people who raise the issue; "economic consequences frame" is framing the impact of an event, specifically the impact of economics on individuals, groups, institutions, regions, or countries.

Generic frames can be used to compare different framing process, while issuespecific frames focus on particular topics (Han, 2007, p. 42-43).

Scholars agreed that at least five factors influence the news frames, with social norms and values, organizational pressures and constraints, pressures of interest groups, journalistic routines and ideological or political orientations of journalists (e.g., Tuchman, 1978; Shoemaker \& Reese, 1996). Scheufele (1999) argued that journalists would frame the news suggested by interest groups or political actors and "incorporated in their coverage of an issue or event" (p. 116). More specifically, two basic ways that the government can impact and interfere in the framing process: state-controlled media leads 
the framing process, or administrative and technological methods utilized to interrupt the “dangerous" framing process (Liao, 2010, p. 70).

Tuchman (1978) defined news as a social institution, for news provide consumers with information, act as "an ally of legitimated institutions" and be located, gathered and disseminated by "professionals working in organization" (p. 4)

Thus, news media plays a significant role in "shaping news consumers" opinions on topics about which they are ignorant" (Tuchman, 1978, p. 2). One of the possible reasons is that news frames offered "a template that guides journalists in assembling facts, quotations, and other story elements into a news story, as well as orients the interpretations of the audience" (Han, 2007, p. 41). Neuman et al. (1992) would agree by stating that audiences depended on "a version of reality built from personal experience, interaction with peers, and interpreted selections from the mass media” (p. 120).

News media has an intimate bond with framing, which is expected to fulfill its functions: "To frame is to select some aspects of a perceived reality and make them more salient in a communicating text, in such a way as to promote a particular problem definition, casual interpretation, moral evaluation, and/or treatment recommendation” (Entman, 1993, p. 52), which can be summarized as: define problems, diagnose causes, make moral judgments, and suggest remedies (Chu, 2010). McQuail (2005) pointed out the default of framing that since framing is involved in the interpretation process, it is likely inevitable for a journalist to “depart from pure 'objectivity' to introduce some (unintended) bias" (p. 379). The balance of information selections should be taken into consideration, since framing will draw attention to specific characteristics of a given issue while reducing attention to others (Cappella \& Jamieson, 1997, p. 45). 
Scheufele (1999) introduced a framing process model, regarding framing as "a continuous process where outcomes of certain processes serve as inputs for subsequent processes". Five steps include: 1) frame building; 2) frame setting; 3) individual-level effects of framing; 4) a link between individual frames; 5) media frames (p. 114).

\section{Recent Framing Studies}

A wealth of research has been done by applying framing theory in recent years within the field of mass communication, particularly in relation to a specific event or a certain issue. Liao (2010) conducted a case study of former New York Gov. Eliot Spitzer's sex scandal in United States. Based on two series of data (one consists of news articles from The New York Times, USA Today and Chinese News Agency; the other was collected from 200 online posts of comments on the scandal of Spitzer from Nytimes.com, USAtoday.com, and sina.com), the author compared the framing effect in China and United States. The modified model from Entman's framing functions were utilized for content analysis, including the functions of problem definition, casual interpretation, moral evaluation, treatment recommendation, and emotional catharsis ( $\mathrm{p}$. 68). The study found that the two nations shared similar characteristics on audience framing process and the concerns of humanity was universal.

In regards to how U.S. media covered and framed China, Chang (2008) examined The Washington Post, The New York Times, Time and Newsweek as representative media, on their portrayals of the Chinese leaders' eight visits to the United States from 1979 to 2006. Most prominent frames such as economics and trade, Taiwan, political relation, human rights, censorship, were also tested in the study (p. 30). After analyzing the 
published text and photos quantitatively and qualitatively, the author concluded that U.S. media provided balanced news coverage both negatively and positively and the extent of coverage was uneven over time.

Another was done by Hauser (2011), which a cross-time comparison was made to see how U.S. media framed China's one-child policy from1970 to 2009. The author selected 83 news articles from The New York Times, The Washington Post and the Christian Science Monitor to examine the dominant speaker group's framing preferences. Hauser found that enforcement frame was dominant before China joined the World Trade Organization (WTO) in 2001, and then shifted to coercion frames. Hauser (2001) also noted that U.S. media had a preference to frame the policy regarding the political implications and issue of coercion.

Chronologically, research about differences on how the Mainland Chinese newspaper (People's Daily and Southern Urban Daily) and Hong Kong newspapers (Wenwei Po and Oriental Daily) framed Chinese migrant workers from 2004 to 2009, was examined (Chu, 2010). In terms of frames, sources, and tone, Chu (2010) found that the Mainland Chinese newspapers shed light on attribution of responsibility and morality frames with a positive stance, while Hong Kong newspapers emphasized the human interest and responsibility frames by presenting neutral side.

According to Scheufele (1999), framing research could be "broken down into research examining frames as independent or dependent variables", based on the study's emphasis on media frames or audience frames (p.107). Following the two aspects of frames ("research examining media versus audience frames and frames as independent versus dependent variables"), he established a "four-cell" typology—media frames as 
dependent/independent variable and individual frames as dependent/independent variable - to make straightforward comparisons within the four cells as well as to examine the extent of linkages to each cell from previous framing studies (p.108). Inspired from Scheufele's typology of framing and regarding the complexity of comparisons on different newspapers from three regions, this study will adaptively focus on media frames, serving as one unique perspective and as a dependent variable, to study Hong Kong 2015 Protest.

The Hong Kong protest has attracted public attention, and numerous newspapers have documented through in-depth and widespread stories; however, there is a void of systematic analysis of the protest coverage. Therefore, this study intends to partially fill that gap. In particular, this study hopes to attain a more in-depth understanding of how media frame the same issue differently from the three regions: Mainland China, Hong Kong and the United States. One of the critical perspectives in framing analysis is to gauge the media frames on a given issue being presented and covered in the news (de Vreese, Peter, \& Semetko, 2001). To sum up, this study strives to answer the following research questions:

RQ 1: What is the most prevalent overall tone toward the Hong Kong 2014 protest and how the tones were presented in different newspapers (China Daily, South China Morning Post, New York Times) from Mainland China, Hong Kong and the United States? 
RQ 2: What were the primary news frames and the dominant frames, and how they were used in Hong Kong 2014 protest coverage among different newspapers (China Daily, South China Morning Post, New York Times)?

RQ 3: Were the five news frames associated with the overall story tones toward the Hong Kong 2014 protest?

RQ 4: Were there significant differences in the use of five news frames (conflict, human interest, responsibility attribution, morality, economic consequences) among the newspapers (China Daily, South China Morning Post, New York Times) from Mainland China, Hong Kong and the United states?

RQ 5: Was there a significant difference in the presentation of the overall story tone (negative, neutral, positive) among the newspapers (China Daily, South China Morning Post, New York Times) from Mainland China, Hong Kong and the United States?

\section{Methodology}

The approach to answer the research questions was to conduct a content analysis of news frames of news articles about the 2014 Hong Kong protest. Three newspapers China Daily (China), South China Morning Post (Hong Kong) and New York Times (United States) - were chosen to compare different frames of Mainland China, Hong Kong and the United States. The various rationales for the selection as data collection for 
this study were: 1) different location of regions serving to diverse audience; 2) various reporting styles and political stances under disparate media systems; 3) high circulation and popularity to gain public trustworthiness and attention.

\section{Newspaper Selection}

China Daily is a national English-language newspaper in mainland China established in 1981, with a total circulation of 900,000 (“About Us", China Daily). To meet with the trend of globalization, China Daily make its commitment to provide services and entertainment and present China and China's news (Herbet, 2001) by targeting at a large range of worldwide audience, who have been paying close attention to China. The China Daily Group has set up branch offices in major cities not only in mainland China such as Beijing and Shanghai, but also foreign cities including New York, Washington D.C., London and Kathmandu. More than 500 professionally trained members are working for news reporting and editing, including over 70 foreign senior journalists from United States, Britain and other countries ("About China Daily", China Daily). China Daily has been playing a significant role in Asia News Network (ANN) to exchange stories and staff with mainstream English media in other parts of Asia, organize events and operate Asian News Photo website. In pursuit of "US issues, Chinese perspectives" (China Weekly News, 2011), China Daily launched China Daily USA Weekly to emphasize on business and cultural issues, which has enhanced the understanding and trust between the two nations. So far, it has received 5,281,863 impressions (thumbs ups) on Facebook page and attracted 422,000 followers on Twitter (China Daily USA edition) since 2009. 
The South China Morning Post is an English-language Hong Kong newspaper, with a circulation of 104,000. Found in 1903, during the late Qing dynasty, the readership of the South China Morning Post was estimated at 349,000 in 2014 and most of readers were classified as highly educated, $78 \%$ having attained a university degree or above (South China Morning Post Marketing Guide, p. 13). Its online version SCMP.com provides access to the retrieval of archive articles dating back to 1993. According to its 2014 Marketing Guide, its online version attracted 3.8 million visitors monthly, 15 million monthly page view, along with 33,800 subscribers (p. 40). Recognitions and reputations are gained through years of award-winning, world-class journalism ad indepth coverage of current affairs locally, regionally and internationally (South China Morning Post). The reports on commemorations of the Tiananmen Square Massacre in 1989 and criticism of Chinese one-child policy in 2013, illustrates the distinguished features of a private-owned newspaper in China: less constraint in neutral stance. It is considered "Hong Kong's Number One English-language Newspaper" (South China Morning Post Marketing Guide, 2014).

The New York Times is an American daily newspaper founded in 1851, which is regarded as the nation's "newspaper of record" and "one of the world's great newspapers.” (Encyclopedia Britannica, 2015). It has established connections with 16 bureaus in the New York region, 11 bureaus within the U.S., and 26 foreign news bureaus, allowing comprehensive coverage both in the United States and around the world. Further, the professional journalists' reporting, which won 117 Pulitzer Prizes in total (New York Times, 2015), has earned the New York Times reputation for authenticity and popularity. Its print version has the largest circulation among other newspapers in the 
United States, up to 639,890 from April 2013 to September 2014 (Statista, n.d.). The online version NYTimes.com had an average circulation of 220,500 during the fiscal years from 2013 to 2014, as well as 28 million monthly unique visitors on mobile devices, including 910,000 paid digital subscribers. (The New York Times Company 2014 Annual Report, p. 2).

\section{Data Collection}

To comprehensively look through the protest development, the study utilized purposive sampling to analyze a census of the news articles from the three newspapers covering the Hong Kong protest during 81 days following the first protest on September 26 , 2014. Since there was no agreed upon date for the ending of protest, this study will consider that date to be December 15, 2014, when police cleared protesters and their camps at Causeway Bay with no resistance. A series of LexisNexis searches for "Hong Kong protest," "Occupy Central protest" and "Umbrella revolution" yielded 105 news articles based on the relevancy. Among them, 13 were from China Daily, 46 were from South China Morning Post, and 46 were from the New York Times. Though the data here were not as large as some quantitative research studies, the same results still could be achieved through an effective sample using the smallest data to represent the population (Wang \& Riffe, 2010).

\section{Coding}

The coding unit was the news article. Each full text of news article was examined and coded by two independent coders. Both coders are journalism major proficient in 
both Chinese and English, as well as attains good knowledge of American and Chinese culture and economy. The coding procedures included the identification of newspaper, published date, column of newspaper, page number, and words length (Dardis, 2006). Given that the 2014 Hong Kong protest presented the features of horse race, drama, conflict, or negativity (Lengauer \& Holler, 2013), the study of generic frames could be used in this study. Thus, the coding methods was referred to Semetko and Valkenburg's (2000) content analysis of press and television news about European politics, which five "most common news frames" (Semetko \& Valkenburg, 2000, p.105) were used for this study: conflict, morality, human interest, economic consequences, attribution of responsibility. Accordingly, a series of 19 questions were revised from Semetko and Valkenburg's 20 coding questions (2000) to measure one of the five news frames. The coders coded each item by marking "yes" (1) or "no" (0). One coding question "Does the story contain visual information that might generate feelings of outrage, empathy-caring, sympathy or compassion" was excluded because this study only examine the texts of the news coverage. After the coders finished answering 19 question items related to different framing variables, a dominant frame was selected for each news article based on the overall news coverage.

When coding these five frames, chances were that some contents could be coded as two or more kinds of framing categories. The following example from South China Morning Post both presented the perspectives of affected life and financial loss caused by the protest:

The blocking of certain main road arteries in Hong Kong has caused severe inconvenience to large sections of the public and serious economic 
loss to shopkeepers, taxi drivers and others. The law permits affected groups to apply to court seeking an injunction to prevent unreasonable interference with those rights and to rule what is reasonable and what is not. (South China Morning Post, 2014, p.14)

Because this study considered the five news frames as separate variables, if two or more framing categories overlapped on the same content (e.g., human interest frame and economic consequence frames were coded as yes on the content shown above), it did not violate the coding rule of exhaustiveness and mutual exclusivity on categories for a variable (Xu, 2013).

\section{Conflict}

The news article was coded as yes if the content reflected disagreement between parties-individuals-groups-countries, one party-individual-group-country reproaches another, or referred to two sides or more than two sides of the problem/issue, or indicated winners or losers of the issue. An example that appeared in New York Times:

Late Tuesday night and Wednesday morning, dozens of demonstrators attempted to break into Hong Kong's legislature, using metal barricades as ramrods to smash through doors and windows of reinforced glass. The police arrested at least six people for assaulting officers and causing "criminal damage" to property. Student groups and pro-democracy lawmakers joined the police in criticizing the participants in the assault, condemning the use of violence. (Forsythe \& Wong, 2014)

Another example from China Daily: 
Hong Kong police on Thursday took long-waited action to clear the largest stronghold of the illegal "Occupy Central” campaign. The successful clearing operation officially spelled defeat for the "umbrella revolution"- the Hong Kong version of the "color revolution". (China Daily, 2014)

The news article was coded as no when its content did not present confrontations among parties-individual-groups-countries from the protest.

\section{Human Interest}

The news article was coded as yes for human interest frame if the story provided a human example or "human face" on the issue, or employed adjectives or personal vignettes that generated feelings of outrage, empathy-caring, sympathy, or compassion, or emphasized how individuals and groups were affected by the issue, or the story went into the private or personal lives of actors. An example that displayed in South China Morning Post:

The Occupy Central movement has brought traffic to a standstill in some places and has affected people's livelihoods. Many people had difficulty getting to work and some schools were closed. (South China Morning Post, 2014, p.12)

Another example appeared in New York Times:

"I feel so guilty about these children," said Frances Ho, a middle-aged woman who visited the tents to offer support on Friday. She shivered with tears when Mr. Wong briefly came out to speak to reporters. "We're using 
them as human shields against the government," she said. "We've left it to the children to fight for democracy." (Buckley \&Wong, 2014, p.10).

The news article was coded as no when its content did not express such emotions as outrage and empathy, or stressed out the affected life caused by the protest.

\section{Attribution of responsibility}

The news article was coded as yes if the content suggested some level of government's ability to alleviate the problem or government's responsibility for the issue, or indicated an individual's (or group of people in society) responsibility for the issue, or suggested solutions to the issue or required urgent action. An example that presented in

\section{South China Morning Post:}

He said that the professionals involved in the Hong Kong protest movement had to take the lead in envisioning a broader and longer-term perspective on the changes they want to bring about and to strategize and plan beyond 2017. (Chou \& Lam, 2014, p.5)

Another example that presented in China Daily:

Chief Executive Leung Chun-ying told reporters on Wednesday that the “Occupy Central" movement was not initiated by the masses, and spontaneous acts by the protesters indicated that the organizers had no control over the crowds. "The Occupy Central movement was obviously not conceived by the masses from Day One more than a year ago. Someone plotted it," said Leung. (Chan, 2014) 
The news article was coded as no when its contents did not attribute responsibility to government, individuals and groups, or did not mention any measures taken to deal with the situation, or did not present government's ability to control the protest development.

\section{Morality}

The news article was coded as yes if the story contained a moral message, or made reference to morality, God and other religious tenets, or offered specific social prescriptions about how to behave. An example that showed in New York Times:

Some protesters said a victory at the barricades would demoralize the police and force the government to offer concessions. Other said that even if victory was out of reach, the conflict would steel protesters for future struggles. (Buckley \& Wong, 2014, p.4)

Another example presented in China Daily:

The defeat of the "Occupy" campaign did not come as a surprise. It failed to rally public support because the occupiers had no legal or moral grounds on which to stand. The latest opinion poll conducted last week shows 83 percent of local people want the protesters to end their actions now. (China Daily, 2014)

The news article was coded as no when its content did not relate any moral message, religious tenets and social prescriptions to the protest. 


\section{Economic consequences}

The news article was coded as yes if the content mentioned financial losses or

gains now or in the future, or costs/degrees of expensive involved in the issue, or referred to economic consequences or pursuing or not pursuing a course of action. An example that exhibited in South China Morning Post:

In the short term, the protests are likely to have had a minimal impact on credit fundamentals. But if the situation continues to deteriorate, the probability of a negative impact will increase. (Steinbock, 2014, p.15) Another example appeared in China Daily:

It is estimated that the "Occupy Central" protests could cost Hong Kong HK $\$ 40$ billion ( $\$ 5.15$ billion). Thirty-six branches of 19 banks in Hong Kong have been closed since the protest started on September 28. There were 30,000 fewer mainland visitors to Hong Kong on Wednesday, the first day of the National Day holiday, than last year. (China Daily, 2014) The news article was coded as no when its content did not emphasize the financial loss and gains, or economic consequences caused by the protest.

\section{Overall Tone}

The overall tone was conceptualized to represent the predominant feeling of the story's tone after one had read the entire article (Dardis, 2006). In this case, the story tone was defined as overall attitudes toward the protesters or the protest group, including negative, positive and neutral. In other words, the news article 
was coded as negative if the overall tone of the article toward the protest/protesters was negative. An example highlighted in China Daily:

Hong Kong's prosperity and stability are hard-won and should be treasured, while Hong Kongers' free will shall not be held hostage to those organizers of the Occupy Central movement who have ulterior motives, critics appealed. (China Daily, 2014)

On the other hand, the news article was coded as positive if the overall tone of the article toward the protest/protesters was supportive. An example illustrated in South China Morning Post:

In Hong Kong, the protests have already yielded some remarkable results. First and most important, a new generation has shown its ability to take on the work of a previous generation who campaigned for democracy; crucially, they have done so by affirming their pride as Hongkongers. (Vines, 2014, p.15)

The news article was coded as neutral when its content presented contrary attitudes from both sides or did not indicate any negative or positive assessments towards the protest.

\section{Intercoder Reliability}

Before the coding procedures, the researcher conducted a training session to explain the coding scheme and provide instructions in details to the other coder. Before actual coding of pertinent contents, the two coders ran three rounds of coding on trial articles to examine the identification of the five frames and overall tone, of which they discussed about the disagreements based on the coding results and reached agreements. 
The two coders separately recorded data for 21 randomly chosen units, which accounted for $20 \%$ of the 105 filtered news articles. As previous researchers have done (Chu, 2010; Xu, 2013; Gottlieb, 2015), Cohen's kappa was utilized to calculate intercoder reliability, which determined "the degree of agreements between two raters is higher than would be expected by chance" (Sun, 2011, p.146). As a result, the reliability for dominant frame (.66), overall tone (.84), conflict (1.00), human interest (.76), attribution of responsibility (.64), morality (.82) and economic consequence (.74) were tested.

Based on Cohen's (1960) suggested interpretation of Kappa result (041-0.60 as moderate, $0.61-0.80$ as substantial, $0.81-1.00$ as almost perfect agreement), the result of intercoder reliability of this study was acceptable.

\section{Results}

Of the 105 news articles selected, the China Daily comprised 12.4\% articles ( $n=13)$, while South China Moring Post and New York Times were both $43.8 \%(n=46)$. RQ1 asked the most frequent overall story tone and how different attitudes towards the Hong Kong protest were presented among different newspapers, Chi-square analysis showed (Table 1) that there were 49 neutral articles (46.7\%), indicating the most prevalent overall story tone, followed by 29 negative articles (27.6\%) and 27 positive $\operatorname{articles}(25.7 \%)$. 
TABLE 1

Total Number of Stories by Newspaper and Overall Tone of Story

\begin{tabular}{lcccc}
\hline & Total $(\% a)$ & China Daily $(\% b)$ & SCMPost $(\% c)$ & NYTimes $(\% d)$ \\
\hline Negative & $29(27.6)$ & $13(12.4)$ & $12(11.4)$ & $4(3.8)$ \\
Neutral & $49(46.7)$ & -- & $25(23.8)$ & $24(22.9)$ \\
Positive & $27(25.7)$ & -- & $9(8.6)$ & $18(17.1)$ \\
Total (\%) & $105(100)$ & $13(12.4)$ & $46(43.8)$ & $46(43.8)$ \\
\hline
\end{tabular}

Note. $\% \mathrm{a}=$ percentage of the total, $\mathrm{n}=105 ; \% \mathrm{~b}=$ percentage within newspaper, $\mathrm{n}=13 ; \% \mathrm{c}=$ percentage within newspaper, $\mathrm{n}=46 ; \% \mathrm{~d}=$ percentage within newspaper, $\mathrm{n}=46$.

With regards to different newspapers, it was also demonstrated that all selected news articles from China Daily presented negative sides $(n=13,100 \%)$ of the protest/protesters, while both South China Morning Post ( $n=25,54.3 \%)$ and New York Times $(n=24,52.2 \%)$ presented neutral attitude toward the protest/protesters as the most prevalent overall tone.

TABLE 2

Frequency of Dominant Frame by Newspaper

\begin{tabular}{lcccc}
\hline & Total $(\% a)$ & China Daily $(\% b)$ & SCMPost $(\% c)$ & NYTimes $(\% d)$ \\
\hline Conflict & $46(43.8 \%)$ & $1(7.7 \%)$ & $16(34.8 \%)$ & $29(63.0 \%)$ \\
Human interest & $27(25.7 \%)$ & $3(23.1 \%)$ & $14(30.4 \%)$ & $10(21.7 \%)$ \\
Responsibility attribution & $25(23.8 \%)$ & $8(61.5 \%)$ & $10(21.7 \%)$ & $7(15.2 \%)$ \\
Morality & $2(1.9 \%)$ & $0(0.0 \%)$ & $2(4.3 \%)$ & $0(0.0 \%)$ \\
Economic consequences & $5(4.8 \%)$ & $1(7.7 \%)$ & $4(8.7 \%)$ & $0(0.0 \%)$ \\
\hline
\end{tabular}

Note. $\% \mathrm{a}=$ percentage of the total, $\mathrm{n}=105 ; \% \mathrm{~b}=$ percentage within newspaper, $\mathrm{n}=13 ; \% \mathrm{c}=$ percentage within newspaper, $n=46 ; \% d=$ percentage within newspaper, $n=46$. 
To address RQ2, which asked the frequency of the occurrence of the dominant frame for each news article. The result showed (Table 2) that the most widely used dominant frame in the news coverage of the protest was conflict ( $n=46,43.8 \%)$, followed by human interest ( $n=27,25.7 \%)$, responsibility attribution $(n=25,23.8 \%)$, economic consequences ( $n=5,4.8 \%)$, and morality $(n=2,1.9 \%)$.

Although the conflict, the frame of human interest and responsibility attribution were the most prevalent dominant frames used in the news coverage among three different newspapers (China Daily, 92.3\%; South China Morning Post, 87\%; New York Times, 100\%), China Daily highlighted the protest with a focus on framing responsibility attribution $(n=8,61.5 \%)$, while New York Times emphasized the conflict perspective of the protest $(n=29,63 \%)$. As for South China Morning Post, which the office is located where the protest occurred, it utilized both conflict $(n=16,34.8 \%)$ and human interest $(n=14,30.4 \%)$ as dominant news frames rather quantitatively equal.

Framing involves selection and emphasis on some aspects of the problem, which on the other hand excludes and undermined other aspects of the problem (Entman, 1993). It was common that a piece of news article utilized more than one news frame in its coverage, aiming to present various perspectives within a story to its diverse audience. By examining a more precise distribution of each frame used in the overall news articles (RQ2), results revealed (Table 3) that most stories tended to present the conflict perspective in their news coverage of the protest, which accounted for 96 (91.4\%) of the 105 stories. It was followed by responsibility attribution ( $n=89,84.8 \%)$, human interest ( $n=71,67.6 \%)$, economic consequences $(n=23,21.9 \%)$ and morality $(n=9,8.6 \%)$. It was 
consistent with the distribution of dominant frames used in the protest coverage (shown in Table 2).

TABLE 3

Frequency of News Frames by Newspaper Title

\begin{tabular}{lcccc}
\hline Frame & Total (a\%) & China Daily (b\%) & SCMPost (c\%) & NYTimes (d\%) \\
\hline Conflict & $96(91.4 \%)$ & $10(76.9 \%)$ & $43(93.5 \%)$ & $43(93.5 \%)$ \\
Human interest & $71(67.6 \%)$ & $9(69.2 \%)$ & $25(55.6 \%)$ & $37(80.4 \%)$ \\
Responsibility attribution & $89(84.8 \%)$ & $12(92.3 \%)$ & $36(78.3 \%)$ & $41(89.1 \%)$ \\
Morality & $9(8.6 \%)$ & $1(7.7 \%)$ & $7(15.2 \%)$ & $1(2.2 \%)$ \\
Economic consequences & $23(21.9 \%)$ & $7(53.8 \%)$ & $13(28.3 \%)$ & $3(6.5 \%)$ \\
\hline
\end{tabular}

Note. $\% \mathrm{a}=$ percentage of the total, $\mathrm{n}=105 ; \% \mathrm{~b}=$ percentage within newspaper, $\mathrm{n}=13 ; \% \mathrm{c}=$ percentage within newspaper, $n=46 ; \% d=$ percentage within newspaper, $n=46$.

Within each newspaper title, it also demonstrated that China Daily applied responsibility attribution ( $n=12,92.3 \%)$ as an essential news frame to cover the protest stories, while both South China Morning Post $(n=43,93.5 \%)$ and New York Times ( $n=43$, 93.5\%) used the conflict frame to reveal the protest development (Table 3). Again, it was accordant with the most frequent use of dominant frame in the news coverage of the protest (See Table 2).

Within each variable of news frame by different newspapers, conflict frame was most frequently used by South China Morning Post and New York Times (both $n=46$, 93.5\%); human interest was the most often used by New York Times ( $n=37,80.4 \%)$;

China Daily utilized responsibility attribution frame and economic consequences frame more often than the other two newspapers $(n=12,92.3 \% ; n=7,53.8 \%)$; morality was applied more frequently by South China Morning Post (n=7, 15.2\%). 
Separate chi-square analyses were run for the five news frame to examine which news frame would be more likely to be associated with negative, neutral or positive overall tone toward the Hong Kong protest (RQ3). Results indicated that only the economic consequences frame was significantly associated with the overall tone of news coverage, $\chi^{2}(2, \mathrm{~N}=105)=14.495, p=.001$. In other words, the overall tone was not affected by which frames were used in the protest coverage, including the news frames of conflict, human interest, responsibility attribution and morality.

TABLE 4

Number of News Frames by Overall Tone of Story

\begin{tabular}{lcccc}
\hline Frame & Negative (a\%) & Neutral (b\%) & Positive (c\%) & $\mathrm{x}^{2}$ \\
\hline Conflict & $4(13.8 \%)$ & $5(10.2 \%)$ & $0(0.0 \%)$ & 3.707 \\
Human interest & $9(32.1 \%)$ & $17(34.7 \%)$ & $7(25.9 \%)$ & 0.621 \\
Responsibility attribution & $3(10.3 \%)$ & $7(14.3 \%)$ & $6(22.2 \%)$ & 1.592 \\
Morality & $27(93.1 \%)$ & $46(93.9 \%)$ & $24(88.9 \%)$ & 0.645 \\
Economic consequences & $16(55.2 \%)$ & $40(81.6 \%)$ & $26(96.3 \%)$ & $14.495^{*}$ \\
& & & & \\
\hline
\end{tabular}

Note. $\% \mathrm{a}=$ percentage within negative, $\mathrm{n}=29 ; \% \mathrm{~b}=$ percentage within neutral, $\mathrm{n}=49 ; \% \mathrm{c}=$ percentage within positive, $\mathrm{n}=27$.

$* p \leq .001$.

To test whether there were any significant differences in the use of news frames among the newspapers from three regions (RQ4), an analysis of variance was conducted separately to compare the use of the five news frames (conflict, human interest, responsibility attribution, morality and economic consequences) in three different newspapers (China Daily, South China Morning Post, New York Times) for the Hong Kong protest coverage. For the news frames who showed significantly different, Tukey's 
honestly significant difference (HSD) was used to examine specific newspapers differ.

The rationale was that Tukey's HSD test was more likely to detect differences, compare to the conservative Scheffé test (Laerd Statistics, n.d.).

\section{TABLE 5}

Mean Scores of the Frequency of Use of News Frames and Overall Tones by Newspaper Title

\begin{tabular}{lcccc}
\hline & China Daily & SCMPost & NYTimes & $F$ \\
& $(\mathrm{~N}=13)$ & $(\mathrm{N}=46)$ & $(\mathrm{N}=46)$ \\
\hline News Frames & & & & \\
Conflict & $.77(.44)$ & $.94(.25)$ & $.94(.25)$ & 2.01 \\
Human interest & $.69(.48)$ & $.56(.50)$ & $.80(.40)$ & $3.37^{*}$ \\
Responsibility attribution & $.92(.28)$ & $.78(.42)$ & $.89(.32)$ & 1.38 \\
Morality & $.00(.00)$ & $.15(.36)$ & $.02(.15)$ & $3.52^{*}$ \\
Economic consequences & $.54(.52)$ & $.28(.46)$ & $.07(.25)$ & $8.63^{* * *}$ \\
\hline Mood & $1.00(.00)$ & $1.93(.68)$ & $2.3(.63)$ & $23.05^{* * *}$ \\
\hline
\end{tabular}

Note. Standard deviations appear in parentheses next to means.

$* p \leq .05, * * * \leq 0.001$

the One-way ANOVA showed (Table 5) that the coverage of different newspapers on the conflict frame was not significant, $F(2,102)=2.01, p=.14$. Besides, there was also not significant use of responsibility attribution frame at the $\mathrm{p} \leq .05$ level in different newspapers $[F(2,102)=1.38, p=.26]$. These two results were consistent with the previous findings that conflict frame $(n=96,91.4 \%)$ and responsibility attribution frame ( $n=89,84.8 \%)$ were the most frequent use of news frames in the overall news articles in the three different newspapers.

In regards to human interest frame, the results demonstrated that the frequency of use of human interest frame was significantly different among the three newspapers, $F(2$, 
$102)=3.37, p=.038$. More specifically, post hoc comparisons using the Tukey HSD test revealed that the mean score for South China Morning Post $(\mathrm{M}=.56, \mathrm{SD}=.50)$ was significantly different than New York Times $(\mathrm{M}=.80, \mathrm{SD}=.40)$. However, China Daily $(\mathrm{M}=.69, \mathrm{SD}=.48)$ did not significantly differ from South China Morning Post and New York Times, in terms of the use of the human interest frame in the protest coverage.

As for morality frame, One-way ANOVA showed that the frequency of use of morality was also significantly different among the three newspaper, $F(2,102)=3.53$, $p$ $=.033$. The Tukey post hoc test indicated that the morality frame used in South China Morning Post $(\mathrm{M}=.15, \mathrm{SD}=.36)$ was significantly different than New York Times $(\mathrm{M}$ $=.02, \mathrm{SD}=.15)$, but China Daily $(\mathrm{M}=.00, \mathrm{SD}=.00)$ did not show significant differences from South China Morning Post and New York Times.

Finally, significant differences were also found in the use of economic consequences frame among the China Daily, South China Morning Post and New York Times, $\mathrm{F}(2,102)=8.63, \mathrm{p}=.00$. Post hoc comparisons with the Tukey HSD tests suggested that the economic consequences frames applied in New York Times $(\mathrm{M}=.07$, $\mathrm{SD}=.25)$ was both significantly different than South China Morning Post $(\mathrm{M}=.28, \mathrm{SD}$ $=.46)$ and China Daily $(\mathrm{M}=.54, \mathrm{SD}=.52)$, while South China Morning Post $(\mathrm{M}=.28$, $\mathrm{SD}=.46)$ did not significantly differed from China Daily $(\mathrm{M}=.54, \mathrm{SD}=.52)$.

RQ5 inquired about the differences of overall story tone in the three newspapers. Similarly, the One-way ANOVA was operated to compare the presentation of the overall tone (negative, neutral, positive) in the protest coverage among the three newspapers (China Daily, South China Morning Post, New York Times). The results demonstrated that the presentation of overall tone was statistically significantly different in the news 
stories of three newspapers, $F(2,102)=23.05, p=.00$ (Table 5). To be more specific, the Tukey post hoc test strongly suggested that the presentation of overall tone in China Daily $(\mathrm{M}=1.00, \mathrm{SD}=.00)$ was significantly different than South China Morning Post $(\mathrm{M}=1.93, \mathrm{SD}=.68)$ and New York Times $(\mathrm{M}=2.30, \mathrm{SD}=.63)$. Meanwhile, South China Morning Post $(\mathrm{M}=1.93, \mathrm{SD}=.68)$ also significantly differed from New York Times $(\mathrm{M}=2.30, \mathrm{SD}=.63)$ on the presentation of overall tones.

To sum up, these results suggested that human interest, morality and economic consequences were the news frames used in disproportionate frequencies depending on the types of newspaper from three regions. It was also indicated that conflict and responsibility attribution were the most common use of news frames in the coverage of the protest event in all newspaper types. Given the fact that the newspapers operated under distinctive media systems, it's reasonable to find that the overall tone towards the Hong Kong protest were presented differently to demonstrate their stances.

\section{Discussion and Conclusion}

The aim in this study was to assess differences in the use of news frames and the overall story tone for the Hong Kong protest in the newspapers China Daily, South China Morning Post and New York Times from Mainland China, Hong Kong and the U.S. To fulfill this, 19 framing questions revised from Semetko et al's (2000) study were used to empirically evaluate the five most common news frames discussed in the previous literature review. The prevalence of these frames were assessed among the three newspapers with highest popularity and authenticity in their regions. The use of news frames examined in this study could promote understanding of what types of framing 
strategies were favored in the coverage of a social protest. More specifically, distinguishing newspapers from different political regions could promote understandings of how the public opinions were shaped within their arenas.

Overall, the preference of the five news frames applied in the protest coverage were: conflict, human interest, economic consequences, and morality. Among them, conflict, human interest and responsibility attribution were the most common use as dominant frames in stories about Hong Kong protest. The most frequent presentation of the overall story tone was neutral, followed by negative and positive.

\section{Framing Hong Kong protest in Chinese mainland newspaper}

First of all, the census of selected news stories from China Daily about the Hong Kong protest in this study was comparatively small compared with other newspapers, which supported Xu's (2014) findings that the propaganda apparatus devoted great efforts to regulate news on political reforms, human rights, or separationist. All 13 examined news articles from China Daily presented negative tones on the Hong Kong protest, showing an accordance of reporting with the official tones under the government's media censorship (Tai, 2014).

Content analysis indicated that the responsibility attribution was the most frequent and dominant frame when Chinese Mainland newspaper such as China Daily reported on the Hong Kong protest. It was followed by the news frames of conflict, human interest and economic consequences. The morality frame rarely appeared in the news coverage. Since the selection of frames reflects political orientation and journalistic practice norms of a newspaper, it was not surprising to find China Daily defined the Hong Kong protest 
as "unlawful street assemblies" (Chan, 2014), accused the initiators with bad intentions of launching the protest, and gave out warnings of foreign governments' intervention.

Unlike the conflict frame was rarely presented in the coverage of social problem (e.g., Chu's (2010) study on framing Chinese migrant workers), China Daily presented the conflicts between the protesters and the police officers during the occupation of the central government office in Hong Kong, with an emphasis on the how difficult was the situation the police faced by being non-violent toward aggressive protesters. The businessmen's financial loss and affected life caused by the protest were highlighted to trigger public's emotions of the empathy for local affected residents and the outrage for the protesters.

\section{Framing Hong Kong protest in Hong Kong newspaper}

In regards of South China Morning Post located in Hong Kong, where the protesters launched the occupation, neutral tone dominated the overall news coverage of the Hong Kong Protest. The frequency of the overall tone of negative and positive were equally presented. It could be accounted for two assumptions:

Firstly, as mentioned before, Hong Kong media enjoys a lower government interference and the media ecology has been directed by the "businessmen-acquired professional press" (Rober, 2003). Previous research on news framing has suggested that politicians, issue advocates and other stakeholders manipulate reporters and editors to deliver their favorable meanings via news media (D’Angelo \& Kuypers, 2010). As a result, the newspaper possibly took the interest of its stake holders and target audience into consideration to manifest an appropriate stance towards the Hong Kong protest. 
Secondly, given the previous Editor-in-Chief Xiangwei Wang was a former CPPCC member serving for the central government in Mainland China, it was possible that he would please the Beijing authority by restrain overly supportive voice toward the protest. Thus, being neutral as the overall tone seemed to be the delicate balance among those interest groups.

According to the results, conflict was the most prevalent in South China Morning Post to frame the Hong Kong protest. Compared to China Daily, the contents stressed out residents' dissatisfaction about the government, as well as the desire to achieve a higher level of democracy. Responsibility attribution was the second frequent frame appeared in the news stories, which mainly attributed the launch of the protest to the central government's broken promise for the universal suffrage. The emotions and attitudes of the Hong Kong residents towards the protest were complicated. Human interest frame was presented in South China Morning Post that how the protesters encouragingly fight for their ideal democracy while the anti-protesters expressed complaints about the affected life and concerns about Hong Kong's future. As Hong Kong's economy has been declining, the negative consequence of the economic loss because of the protest was also given concerns in the news coverage.

\section{Framing Hong Kong protest in the U.S. newspaper}

As a representative of U.S. media, New York Times exhibited the unique feature of a liberal media system: objectivity. Overall, the dominant tone toward the Hong Kong protest was neutral. However, it was noteworthy that New York Times also presented a far more frequent tone of positive than negative in the coverage of the Hong Kong protest. 
Since the New York Times has been operated under the highest level of democracy and press freedom between Mainland China and Hong Kong, which democracy and human rights has been highly valued (Chen, 2013), it was reasonable that the newspaper exhibited a dominant attitude of pro-democracy and positivity towards Hong Kong people launching a protest to fight for their rights of universal suffrage.

Similar to South China Morning Post on Hong Kong protest coverage, the empirical data indicated that New York Times significantly utilized the conflict aspect to frame the protest. Headlines such as "Violent clashes between police and demonstrators erupt in Hong Kong” (Bradsher \& Buckley, 2014) and "Afer tear gas, Hong Kong protesters defy officials' call to disperse" (Ramzy \& Wong, 2014) presented a direct sense of the conflict on the protesters against the police and officials. Besides, the newspaper seemed to also focus on attributing the responsibility to the central government and Hong Kong officials' decision, by indicating supports of the protest from other Western governments such as Britain, and even Taiwai. Human interest frame was also applied into the reporting showing Hong Kong protesters' outrage and disappointment toward the government and the difficulties to claim their rights back. Morality and economic consequences were rarely presented in the news stories.

\section{Framing Hong Kong protest with the overall tone}

Differentiating from Xu's (2014) findings that all the six framing devices used in the study presented associations with the overall tone of the Occupy Wall Street, this study showed that only the economic consequences frames displayed an association with the overall tone of the news coverage of the Hong Kong protest. A possible reason could 
be assumed that the economic consequences caused by a social protest were objectively more likely to produce negative effects, which led to an overall negative tone of the story, especially when the economic consequences was considered as a dominant frame highlighted in a news article. While Xu's (2014) study only examined two newspapers (New York Times and USA Today) within American media system, this study looked at China Daily, South China Morning Post, and New York Times under different media systems from Mainland China, Hong Kong and America. Thus, it was understandable that the other frames-conflict, human interest, responsibility attribution, morality- did not present correlations with the overall tone, given considerations of the newspapers have the options to choose from the two-sided effects of using the frames to shape their intended public opinions to target audience.

All in all, the content analysis based on the empirical data implied that the use of different news frames to shape public opinions were different from newspapers within their own media system. It responded to the previous research findings that news frames were influenced by interest groups, social norms and values and political orientations of the newspapers (e.g., Tuchman, 1978; Shoemaker \& Reese, 1996; Scheufele, 1999; Liao, 2010). It was worth noting that newspaper in Hong Kong such as South China Daily embodied both authoritarian and liberal perspectives in the protest coverage, keeping a delicate balance under the political principle of "One Country, Two Systems".

\section{Limitations}

Like most research studies, limitations for this study was inevitable. First of all, only one newspaper in print was selected to represent its own region from Mainland 
China, Hong Kong and the United States. Although the selections of the newspaper were carefully gauged on the principles of authenticity and popularity with higher circulation and quality, it could not be denied that different types of newspapers within a country still present discrepancy in terms of the newspapers' orientation of the interest groups such as stake holders and target audience. One newspaper is impossible to comprehensively represent the news media as a whole. Future research can enlarge the samples of newspaper types as well as expand the media types into other media source (e.g., social media).

Another concern was about the news frames examined for this study. Despite the five frames (conflict, human interest, responsibility attribution, morality, economic consequences) were proved to be the most common frames in news coverage, chances were that some other frames, which would be more suitable in the case of the protest coverage, were ignored in this study. For example, other framing device such as lawlessness, show, ineffective goals, public disapproval could also be examined in the protest framing study (Xu, 2014). Future researchers should not be restrained from using other types of news frames to examine on other particular topics.

Given the consideration of this study's focus on analyzing the context from the news articles, potential for further research may want to also look at the visual framing strategies in a protest or other particular topics. The selective use of photographs can also present a strong, forceful idea about a distant conflict (Parry, 2010). Therefore, the visual framing, like content framing, also effectively functions to shape public opinions. 
Last but not least, another avenue for a more in-depth and extensive research of the protest framing strategy was recommended to compare two or more protest within a country and beyond, with a longitudinal perspective. For example, new findings would be discovered by comparisons between the different framing strategies used in Hong Kong protest and Occupy Wall Street, or the changes of news frames between recent Hong Kong protest recently and dated Tiananmen Square. 


\section{Appendix}

\section{Content Analysis Coding sheet}

1. Coding Unit Number:

2. Coder:

3. Source: news from

4. Date Coded: (e.g. 021816)

5. Overall Tone: (if negative, code 1; neutral, code 2; positive, coder 3)

Frames: mark each question as yes (1) or no (0).

\section{Conflict frames}

6. Does the story reflect disagreement between parties-individuals-groups-countries?

7. Does one party-individual-group-country reproach another?

8. Does the story refer to two sides or to more than two sides of the problem or issue?

9. Does the story refer to winners or losers?

\section{Human interest frame}

10. Does the story provide a human example or "human face" on the issue?

11. Does the story employ adjectives or personal vignettes that generate feelings of outrage, empathy-caring, sympathy, or compassion?

12. Does the story emphasize how individuals and groups are affected by the issue/problem?

13. Does the story go into the private or personal lives of the actors? 


\section{Attribution of responsibility frame}

14. Does the story suggest that some level of the government has the ability to alleviate the problem?

15. Does the story suggest that some level of the government is responsible for the issue/problem?

16. Does the story suggest solution(s) to the problem/issue?

17. Does the story suggest that an individual (or group of people in society) is responsible for the issue-problem?

18. Does the story suggest the problem requires urgent action?

\section{Morality frame}

19. Does the story contain any moral message?

20. Does the story make reference to morality, God, and other religious tenets?

21. Does the story offer specific social prescriptions about how to behave?

\section{Economic consequences frame}

22. Is there a mention of financial losses or gains now or in the future?

23. Is there a mention of the costs/degree of expensive involved?

24. Is there a reference to economic consequences of pursuing or not pursuing a course of action?

25. What is dominant frame in this unit?

1. Conflict frame 
2. Human interest frame

3. Attribution of responsibility frame

4. Morality frame

5. Economic consequence frame 


\section{References}

Bastin, M. (2014, October 22). Weakening US stoking HK 'protest'. China Daily.

Retrieved December 20, 2015, from http://usa.chinadaily.com.cn/opinion/201410/22/content $18781175 . h t m$

BBC. (2014, December). Hong Kong protests: timeline of the occupation. BBC News. Retrieve September 20, 2015 from http://www.bbc.com/news/world-asia-china$\underline{30390820}$

Benson, R., Blach-Ørsten, M., Powers, M., Willig, I., \& Zambrano, S. V. (2012). Media systems online and off: Comparing the form of news in the United States, Denmark, and France. Journal of Communication, 62(1), 21-38.

doi:10.1111/j.1460-2466.2011.01625.x

Bill of Rights.

(1971).http://www.archives.gov/exhibits/charters/bill of rights transcript.html

Cappella, J. N., \& Jamieson, K. H. (1997). Spiral of cynicism: the press and the public good. New York, NY: Oxford University Press.

Chan, J. (2007). Freedom of the press: The first ten years in the hong kong special administrative region. Asia Pacific Law Review, 15(2), 163-191

Chang, Y. (2008). Framing China: how US media reported eight US state visits by top Chinese leaders.

Chase, S. (2014, September 30). Ottawa 'supportive' of demonstrations in Hong Kong. The Globe and Mail. Retrieved September 28, 2015, from 
http://www.theglobeandmail.com/news/politics/ottawa-supportive-ofdemonstrations-in-hong-kong/article20837632/

Chen, Jun. (2013). Framing foreign news: U.S. coverage of Chinese protesters, 1990 to 2011 (Master dissertation). Retrieved from Masters Abstracts International. (Order number: 1551134)

Cheung, T. (2014, August 31). Hong Kong's candidate nominating system out of balance, says Beijing scholar. South China Morning Post. Retrieved September 20, 2015 from http://www.scmp.com/news/hong-kong/article/1582079/beijing$\underline{\text { scholar-says-hong-kongs-candidate-nominating-system-out }}$

China Daily. (n.d.). About China Daily. Retrieved December 20, 2015 from http://www.chinadaily.com.cn/cd/introduction.html

China Daily. (n.d.). About Us. Retrieved December 20, 2015 from http://www.chinadaily.com.cn/static e/2011about.html China Weekly News. (2011, September). China Daily Launches US Weekly. Retrieved December 20, 2015 from http://find.galegroup.com/gic/infomark.do?\&source=gale\&idigest=8e9ba5854644 $\underline{01187440005 \mathrm{a} 9380 \mathrm{bfe} 2 \& \text { prodId }=\mathrm{GIC} \& \text { userGroupName }=\operatorname{morg} 77564 \& \operatorname{tabID}=\mathrm{T} 0}$ $\underline{04 \& \text { docId }=\text { A267232167\&type }=\text { retrieve \&contentSet }=I A C-}$ $\underline{\text { Documents\&version }=1.0}$

Chu, K. (2010). Framing Chinese migrant workers: A comparison of media coverage in Mainland China and Hong Kong.

Chu, K. (2014, September 29). U.S. Consulate in Hong Kong urges restraint after weekend protests. The Wall Street Journal. Retrieved September 28, 2015, from 
http://www.wsj.com/articles/u-s-consulate-in-hong-kong-urges-restraint-afterweekend-of-protests-1411969197

Cohen, J. (1960). A coefficient of agreement for nominal scales. Educ Psychol Meas, 20, $37-46$.

Cullen, R. (1998). Media Freedom in Chinese Hong Kong. Transnat'l Law,11, 383-418.

Curran, E. (2014, September 29). Hong Kong police use of tear gas on pro-democracy protesters is questioned. The Wall Street Journal. Retrieved September 21, 2015 from http://www.wsj.com/articles/hong-kong-police-use-of-tear-gas-on-prodemocracy-protesters-is-questioned-1411991105

D'angelo P., \& J. Kuypers. J. A. (2010). Doing news framing analysis: empirical and theoretical perspectives. (Ed.). New York, NY: Routledge.

Dardis, F. E. (2006). Marginalization devices in US press coverage of Iraq war protest: A content analysis. Mass Communication \& Society, 9(2), 117-135.

de Vreese, C. H., Peter, J., \& Semetko, H. A. (2001). Framing politics at the launch of the Euro: Across-national comparative study of frames in the news. Political Communication, 18, 107-122.

Entman, R.M. (1993). Framing: Towards clarification of a fractured paradigm. Journal of Communication, 43(4), 51-58.

Faulconbridge, G. (2014, September 30). Cameron says deeply concerned about Hong Kong clashes. Reuter. Retrieved

September 29, 2015, from http://uk.reuters.com/article/2014/09/30/uk-hongkong-chinabritain-idUKKCNOHP0JH20140930 
Federal Communication Commission. (1934). What we do. Retrieved October 11, 2015, from https://www.fcc.gov

Forsythe, M. (2014, October, 23). U.N. Human Rights Panel urges China to allow free elections in Hong Kong. The New York Times. Retrieved September 28, 2015, from http://www.nytimes.com/2014/10/24/world/asia/un-urges-china-to-allow$\underline{\text { free-elections-in-hong-kong.html? } \mathrm{r}=0}$

Freedom House. (2015). About the Freedom of the Press. Retrieved October 8, 2015, from https://freedomhouse.org/report-types/freedom-press

Gitlin, T. (1980). The whole world is watching: Mass media in the making \& unmaking of the new left. Berkeley: University of California Press.

Goffman, E. (1974). Frame analysis: An essay on the organization of experience. Harvard University Press.

Gottlieb, J. (2015). Protest news framing cycle: How the new york times covered occupy wall street. International Journal of Communication, 9, 231-253.

Han, G. (2007). Mainland China frames Taiwan: How China's news websites covered Taiwan's 2004 presidential election. Asian Journal of Communication, 17(1), 4057.

Hauser, N. W. (2011). American discourse on China: a cross-time comparison of US news framing of China's one-child policy, 1979-2009(Doctoral dissertation, University of Missouri--Columbia).

Herbert, J. (2001). Practising global journalism: exploring reporting issues worldwide. Taylor \& Francis. 
Hong Kong Journalists Association (HKJA) . (2002). Over 50\% journalists think that press freedom has deteriorated since the handover with 30\% admit having committed self-censorship

Hong Kong Journalists Association (HKJA) . (2011). Hong Kong Journalists Association calls for resoluteness of the profession. Retrieved October 10, 2015, from http://www.hkja.org.hk/site/portal/Site.aspx?id=A1-661\&lang=en-US

Hong Kong Journalists Association (HKJA) . (2011). 2011 Annual Report: Two Systems Compromised, Free Expression Under Threat in Hong Kong http://www.hkja.org.hk/site/portal/Site.aspx?id=A1-937\&lang=en-US

Hong Kong Journalists Association and Article 19 (eds). (1997). The die is cast: annual report on freedom of expression. Hong Kong: Article 19 and HKJA.

King, Gary, Jennifer Pan, and Margaret Roberts. 2013. How censorship in China allows government criticism but silences collective expression American Political Science Review .107, 2: 1-18.

Laerd Statistics. (n.d.). One-way ANOVA. Retrieved March 10, 2016 from https://statistics.laerd.com/statistical-guides/one-way-anova-statistical-guide4.php

Lengauer, G., \& Holler, I. (2013). Generic frame building in the 2008 austrian elections. Public Relations Review, 39(4), 303-314. doi:10.1016/j.pubrev.2013.07.010

Liao, W. (2010). Framing political sex scandal in cross-cultural context between China and the United States: a comparative case study. China Media Research, 6(2). McHugh, M. L. (2012). Interrater reliability: The kappa statistic. Biochemia Medica, $22(3), 276$. 
McManus, John H. 1994. Market-Driven Journalism. Let the Citizen Beware? Thousand Oaks, CA: Sage.

McQuail, D. (2005). McQuail's Mass Communication Theory. Thousand Oaks, CA: Sage Publications.

Neuman, R.W., Just, M.R., Crigler, A.N. (1992). Common knowledge. News and the construction of political meaning. Chicago: University of Chicago Press.

(n.d.) Pulitzer Prizes. New York Times. Retrieved on November 3, 2015, from http://www.nytco.com/pulitzer-prizes/

(n.d.). Why SCMP. South China Morning Post. Retrieved on September 28, 2015, from http://advertising.scmp.com/marketer/why.asp

Parry, K. (2010). A visual framing analysis of british press photography during the 2006 israel- lebanon conflict. Media, War \& Conflict, 3(1), 67-85.

doi: $10.1177 / 1750635210353679$

Robert, F.A. (2003). Hong Kong in Transition: One Country, Two systems. London: Rutledge Curzon.

Scheufele, D.A. (1999). Framing as a theory of media effects. Journal of Communication. 49(1), 103-122.

Semetko H. \& Valkenburg, P.M. (2000). Framing European politics: A content analysis of press and television news. Journal of Communication, 50(2), 93-109.

Shoemaker, P. J. \& Reese, S.D.(1996). Mediating the message: Theories of influence on mass media content. New York, NY: Longman Publishers USA.

Staff Reporters. (2014, September 29). Occupy central-day two: full report of the day's events. South China Morning Post. Retrieved September 21, 2015 from 
http://www.scmp.com/news/hong-kong/article/1603762/live-severe-disruptionexpected-day-dawns-occupied-hong-kong

Statista. (n.d.). New York Times: circulation 2013-2014. Retrieved September 28, 2015, from http://www.statista.com/statistics/193792/average-paid-circulation-of-thenew-york-times/

Stockmann, Daniela. 2013. Media Commercialization and Authoritarian Rule in China. New York: Cambridge University Press.

South China Morning Post. (2014). South China Morning Post Marketing Guide. Retrieved on September 28, 2015, from http://advertising.scmp.com/marketing guide/pdf/SCMP_marketing_guide hong kong_2015.pdf

Sun, S. (2011). Meta-analysis of cohen's kappa. Health Services and Outcomes Research Methodology, 11(3-4), 145-163. doi:10.1007/s10742-011-0077-3

Tai, Q. (2014). China's media censorship: A dynamic and diversified regime. Journal of East Asian Studies, 14(2), 185-209.

The editors of Encyclopaedia Britannica. (2015). The New York Times. Retrieved September 28, 2015, from http://www.britannica.com/topic/The-New-York$\underline{\text { Times }}$

The New York Times. (2014). The New York Times 2014 annual report. Retrieved September 28, 2015, from http://investors.nytco.com/files/doc financials/annual/2014/2014-Annual-Report(FINAL).pdf 
Tuchman, G. (1978). Making news: A study in the construction of reality.The Free Press: New York.

Wang, X., \& Riffe, D. (2010). An exploration of sample sizes for content analysis of the New York Times web site. Retrieved from November 8,2015, from http://wjmcr.org/vol20

Who Owns the News Media . (2012). The dashboard. Retrieved from October 11, 2015, from http://www.stateofthemedia.org/media-ownership/

Wilkins, K.G. (2008). Hong Kong television: same as it ever was? In Zhu, Y. \& Berry, C. (ed), TV China. Bloomington, IN: Indiana University Press

Wimmer, D. R. \& Dominick, R. J. (2006). Mass media research: an introduction. Australia; Thomson Wadsworth. 141.

Xu, K. (2013). Framing Occupy Wall Street: A Content Analysis of The New York Times and USA Today. International Journal of Communication, 7, 21.

Zhou, W. (2009). Hong kong media and freedom of speech: a case study of phoenix television's "current affairs debate". (Order No. MR49732, University of Calgary (Canada)). ProQuest Dissertations and Theses, 88. Retrieved from http://search.proquest.com/docview/304834654?accountid=2837 